\title{
Evaluasi Dosis Fraksionasi Sinar Gamma dalam Melemahkan Parasit Malaria Plasmodium berghei pada Mencit untuk Pengembangan Vaksin Iradiasi
}

\author{
Mukh Syaifudin $^{1}$, Hartati Mahmudah ${ }^{2}$, Teja Kisnanto ${ }^{1}$, Devita Tetriana ${ }^{1}$, Siti \\ Nurhayati $^{1}$, Tur Nurhayati ${ }^{1}$, Tur Rahardjo ${ }^{1}$, Darliana ${ }^{1}$ \\ ${ }^{1}$ Kelompok Radiobiologi, Pusat Teknologi Keselamatan dan Metrologi Radiasi, BATAN \\ ${ }^{2}$ Program Studi Farmasi, FMIPA, Institut Sains dan Teknologi Nasional, Jakarta \\ E-mail: much_syaifudin@batan.go.id
}

\begin{abstract}
Malaria is still a big problem in Indonesia so that the development of vaccine is urgently needed. However, the immunity is not fully obtained in host that may be due to high dose of irradiation to parasites. This study aimed to determine the infectiveness of Plasmodium berghei malaria parasite in mice after being irradiated with gamma fractionated dose of $0 \mathrm{~Gy}, 100+50,100+75$ and 100+100 Gy at a dose rate of $717 \mathrm{~Gy} / \mathrm{h}$. Observation of the percentage of parasitic appearance forms (parasitemia) such as trophozoite (including ring) and schizont was done on thin blood smears stained by Giemsa from observation day 2 to 20 post injection. The results showed that fractionated irradiation was effectively suppressed the growth of parasites in the blood of mice for all treatment groups except the fractionation dose of 100+75 Gy. Mice injected with a dose of 100+100 Gy have a stable body weight during days of observation, supported by a relatively normal macroscopic appearance of the liver and spleen. It was concluded that fractionated dose of 100+100 Gy is most effectively weakened the parasite for malaria vaccine material supported by body weight stability and better condition of liver-lymph organ.
\end{abstract}

Keywords : Plasmodium berghei, vaccine, gamma rays, fractionation dose, mouse

\begin{abstract}
Abstrak
Malaria masih merupakan pemasalahan besar di Indonesia sehingga pengembangan vaksin sangat diperlukan. Akan tetapi, imunitas pada inang belum sepenuhnya diperoleh yang kemungkinan disebabkan oleh tingginya dosis iradiasi pada parasit. Penelitian ini bertujuan untuk mengetahui daya infektif parasit malaria Plasmodium berghei pada mencit setelah diiradiasi gamma fraksinasi $0 \mathrm{~Gy}, 100+50,100+75$ dan 100+100 Gy pada laju dosis 717 Gy/jam. Diamati persentase kemunculan bentuk-bentuk parasit (parasitemia) seperti tropozoit (termasuk cincin) dan skizon pada apusan darah tipis yang diwarnai Giemsa, dari hari pengamatan ke-2 hingga 20 pasca penyuntikan. Hasil penelitian menunjukkan bahwa iradiasi fraksinasi efektif menekan pertumbuhan parasit dalam darah mencit untuk semua perlakuan kecuali dosis fraksinasi 100+75 Gy. Mencit disuntik dosis 100+100 Gy memiliki berat badan yang stabil selama pengamatan, didukung oleh tampilan makroskopis hati dan limpa yang relatif normal. Disimpulkan bahwa iradiasi fraksinasi 100+100 Gy paling efektif melemahkan parasit sebagai bahan vaksin malaria, didukung oleh kestabilan berat badan dan kondisi organ hati-limpa yang lebih baik.
\end{abstract}

Kata kunci : Plasmodium berghei, vaksin, sinar gamma, dosis fraksinasi, mencit

\section{Pendahuluan}

Malaria merupakan penyakit infeksi yang disebabkan oleh protozoa Plasmodium dan ditularkan oleh nyamuk Anopheles betina. ${ }^{1}$ Penyakit ini sampai sekarang masih merupakan masalah kesehatan di banyak negara, terutama di daerah tropis dan sedang berkembang.
Sekitar 3,2 milyar penduduk tinggal di daerah endemis malaria dengan kelompok yang paling berisiko adalah bayi, anak balita dan ibu hamil. ${ }^{1,2}$ Tiga ratus juta penduduk setiap tahunnya dan 2-4 juta diantaranya meninggal dunia akibat penyakit ini. Di Indonesia saat ini tercatat angka kesakitan dan kematian akibat 
malaria masih cukup tinggi (sekitar $80 \%$ kasus ditemukan di wilayah timur) disebabkan oleh berbagai faktor, diantaranya adalah resistensi plasmodium terhadap obat-obat antimalaria maupun nyamuk yang resisten terhadap insektisida. ${ }^{3,4}$ Saat ini sedang dijalankan Program Eliminasi Malaria dimana diharapkan pada tahun 2030 kasus transmisi malaria lokal telah menurun hingga nol. ${ }^{5}$

Dalam upaya pengendalian malaria yaitu Roll Back Malaria (RBM) atau Gerakan Berantas Malaria (Gebrak Malaria) telah dicanangkan salah satu strategi usaha mengontrol malaria yaitu pengembangan vaksin. ${ }^{6}$ Berbagai metode telah digunakan untuk melemahkan mikroorganisme penyebab penyakit untuk memperoleh bahan vaksin, salah satu diantaranya adalah dengan iradiasi gamma terhadap parasit. ${ }^{7}$ Penentuan dosis iradiasi sinar gamma optimal untuk melemahkan parasit sebagai bahan dasar vaksin dengan menggunakan model Plasmodium berghei stadium eritrositik telah banyak dilakukan, dimana daya infeksi parasit menurun akibat radiasi dan dapat mengaktifkan respon imun pada mencit. ${ }^{8}$ Pengaruh dosis iradiasi terhadap daya infeksi parasit tersebut dievaluasi dari periode prepaten, persentase parasitemia, dan mortalitas mencit. Hasil studi menunjukkan bahwa dosis iradiasi 150-175 Gy merupakan dosis yang optimal untuk melemahkan parasit yang ditunjukkan oleh periode prepaten yang panjang, parasitemia dan kematian mencit yang rendah. Perlakuan booster (inokulasi kedua pada dua minggu setelah inokulasi pertama) dengan $P$. yoelii dan $P$. berghei yang diradiasi 150 dan 175 Gy mampu meningkatkan respon imun mencit karena terjadi penurunan densitas parasit dalam darah. Pada penelitian respon imun non spesifik (makrofag dan limfosit) pada model $P$. berghei menunjukkan dosis 150 Gy memberikan respon imun yang lebih baik dibandingkan dosis 175 Gy. ${ }^{9-11}$ Namun respon imun tersebut belum mencapai $100 \%$ yang mungkin disebabkan karena kematian sebagian parasit akibat tingginya dosis iradiasi.

Dengan berpedoman pada prosedur radiasi terbagi (fraksinasi) yang terbukti lebih efektif mematikan sel kanker dan mempertahankan sel sehat disekitarnya, ${ }^{12,13}$ maka pada penelitian ini dievaluasi daya infeksi parasit malaria rodensia $P$. berghei stadium eritrositik setelah diiradiasi dengan variasi dosis fraksinasi 100 dan 50 Gy $(100+50$ Gy), $100+75$ Gy dan 100+100 Gy pada laju dosis 717 Gy/jam. Penelitian ini dilakukan untuk menentuan dosis iradiasi fraksinasi sinar gamma optimal untuk melemahkan parasit sebagai bahan dasar pembuatan vaksin.

\section{Metode}

Mikroorganisme parasit yang digunakan pada penelitian ini adalah Plasmodium berghei strain ANKA yang diperoleh dari Lembaga Biologi Molekuler Eijkman Jakarta berupa darah mencit terinfeksi parasit. Hewan uji yang digunakan adalah mencit Mus musculus $L$. Strain Swiss Webster putih jantan berumur sekitar 3 - 4 bulan dengan berat badan $30-$ $35 \mathrm{~g}$ yang diperoleh dari Badan Penelitian dan Pengembangan Kesehatan, Kementerian Kesehatan, Jakarta. Penelitian ini dilakukan setelah mendapat ijin etik dari Komisi Etik Penelitian Kesehatan, Badan Litbang Kesehatan, Kementerian Kesehatan (No. KE.01.05/EC/419/2012, tanggal $25 \mathrm{Mei}$ 2012).

Penelitian ini diawali dengan pengembangbiakan parasit $P$. berghei secara in vivo ke dalam tubuh mencit dengan penyuntikan secara intraperitoneal sebanyak $10^{6}$ parasit/mL. Dua atau 3 hari setelah penyuntikan, satu tetes darah diambil dari ekor mencit untuk dibuat sediaan apusan darah tipis pada preparat kaca dan diwarnai dengan menggunakan pewarna Giemsa 5\% selama 10 menit. Pengambilan darah ekor, pembuatan preparat dan pewarnaan dilakukan sesuai dengan prosedur baku. ${ }^{14}$ Dilakukan 
penghitungan parasitemia di bawah mikroskop dengan membandingkan jumlah sel darah merah yang tidak terinfeksi parasit dan sel darah merah yang terinfeksi dan dihitung dalam setiap 10 lapangan pandang.

Persentase parasit dalam darah dihitung dengan rumus :

$$
\text { Persentase parasitemia }=\frac{\text { sel darah merah yang terinfeksi }(\text { cincin,trofozoid,skizon })}{\text { total hitung sel darah merah }} \times 100
$$

Apabila parasitemia mencapai $10-15 \%$, mencit dianastesi dengan eter, dibedah dan diambil darahnya langsung dari jantung dengan menggunakan syringe $1 \mathrm{~mL}$ yang telah diisi antikoagulan. Sampel darah ini digunakan sebagai stok. Selanjutnya sampel darah terinfeksi parasit tersebut (sekitar $1 \mathrm{~mL}$ untuk tiap perlakuan) diiradiasi sinar gamma menggunakan irradiator IRPASENA Co-60 di Pusat Aplikasi Isotop dan Radiasi-BATAN Pasar Jum'at dengan variasi dosis fraksinasi 0 Gy (kontrol), 100+50 Gy, 100+75 Gy, $100+100$ Gy pada laju dosis 717 Gy/jam, dengan interval iradiasi fraksinasi pertama dan kedua adalah sekitar 5 menit.

Plasmodium berghei dalam darah yang telah diiradiasi $(0,5 \mathrm{~mL}$ yang mengandung sekitar $10^{6}$ parasit $/ \mathrm{mL}$ ) kemudian disuntikkan ke 4 kelompok mencit (terdiri dari 3 ekor per kelompok, sesuai dosis fraksinasi) melalui rute intraperitoneal. Dua hari pasca penyuntikan dilakukan pemeriksaan parasitemia dari darah ekor pada masingmasing kelompok, dengan dibuat sediaan apusan darah tipis dan diwarnai Giemsa $5 \%$, dilakukan pengamatan parasit (bentuk tropozoit dan skizon serta gametosit atau bentuk lainnya) menggunakan mikroskop dengan pembesaran 1000x dengan bantuan minyak imersi. Pengambilan sampel dilakukan setiap 2 hari sekali hingga 20 hari pasca penyuntikan. Berat badan mencit dipantau dengan menimbang pada hari-hari pengamatan dengan timbangan digital. Di samping itu juga dilakukan pengamatan perubahan, tampilan (bentuk dan ukuran) dan warna hati dan limpa pada pembedahan mencit di hari ke 20 .

\section{Hasil}

Pengamatan parasitemia didasar-kan pada bentuk atau tahapan perkembangan parasit dalam darah meliputi tropozoit, skizon dan gametosit pada hari ke 2 sampai hari ke 20 pasca penyuntikan parasit iradiasi. Dari hasil pengamatan mikroskopis terlihat bahwa perkembangan parasit tropozoit bentuk cincin untuk mencit kelompok dosis 0 Gy (kontrol) meningkat pada hari ke 4 yang kemudian menurun hingga hari ke 8 dan kembali naik serta mencapai puncaknya pada hari ke 20. Untuk kelompok dosis fraksinasi 100+50 Gy parasitemia sedikit mengalami peningkatan tetapi pada hari ke 8 menurun. Pada kelompok dosis fraksinasi $100+75$ Gy perkembangan parasit tropozoit bentuk cincin mengalami peningkatan, tetapi menurun setelah hari ke 13. Pada kelompok dosis fraksinasi 100+100 Gy jumlah parasit bentuk cincin tetap rendah sampai hari pengamatan ke 20. Tidak ditemukan adanya tropozoit dan skizont untuk dosis 100+50 dan 100+100 Gy pada hari-hari pengamatan. Dari data tersebut diketahui bahwa iradiasi efektif menekan pertumbuhan parasit dalam darah mencit untuk semua perlakuan kecuali dosis 100+75 Gy (Gambar 1). Tidak ditemukan adanya tahapan parasit bentuk lain seperti gametosit. 


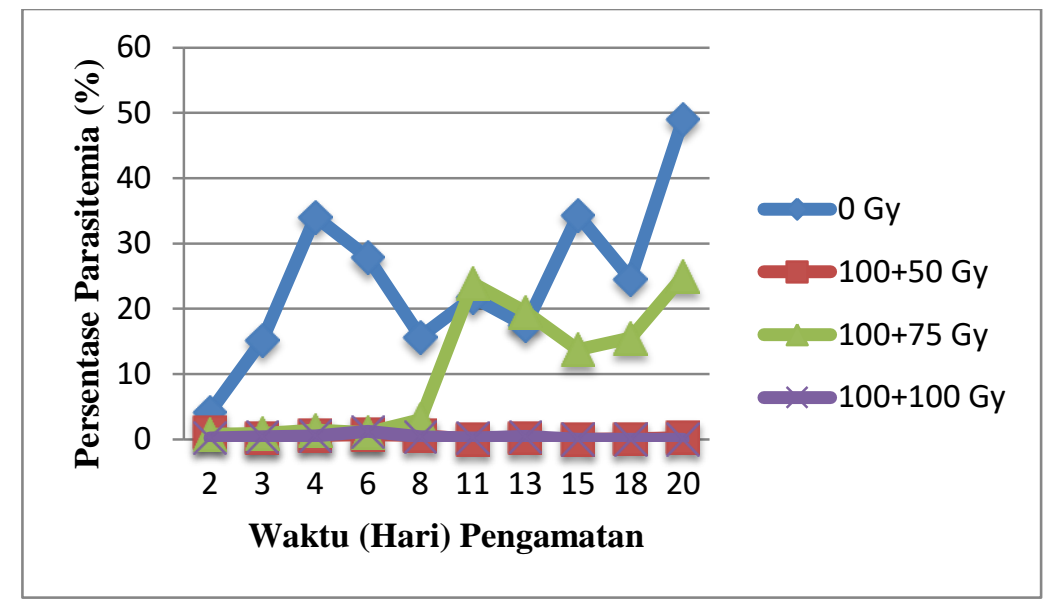

Gambar 1. Persentase parasitemia mencit setelah disuntik parasit iradiasi fraksinasi 0 Gy, 100+50 Gy, 100+75 Gy, 100+100 Gy (laju dosis 717 Gy/jam).

Pada kelompok mencit untuk dosis 0 Gy kepadatan parasit stadium tropozoit terus meningkat pada hari-hari pengamatan bahkan terjadi perkembangan yang sangat tinggi pada hari ke 13 dan 18. Pada kelompok dosis fraksinasi 100+50 Gy dan
100+100 Gy tidak terjadi perkembangan parasit bentuk tropozoit ini, namun pada kelompok dosis $100+75$ Gy parasit muncul kembali pada hari ke 8 dan meningkat hingga hari ke 18 (Gambar 2).

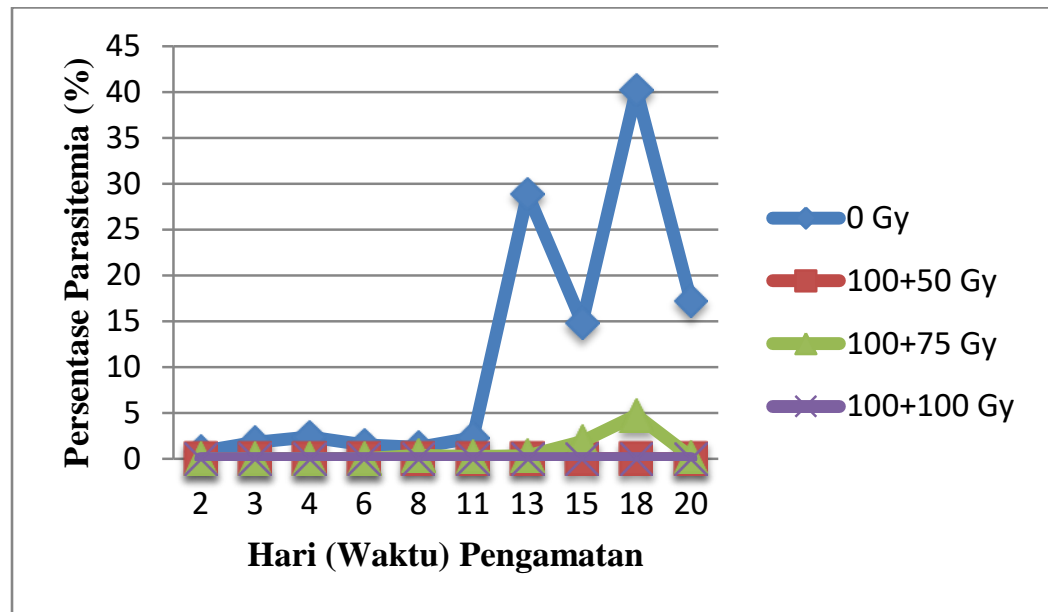

Gambar 2. Persentase parasitemia berdasarkan stadium tropozoit dalam darah mencit setelah disuntik parasit iradiasi fraksinasi $0 \mathrm{~Gy}, 100+50 \mathrm{~Gy}, 100+75 \mathrm{~Gy}$, 100+100 Gy (laju dosis 717 Gy/jam).

Hasil pengamatan kepadatan parasit stadium skizon dapat dilihat bahwa pada dosis 0 Gy terus mengalami peningkatan yang cukup signifikan pada hari ke 13 , sedangkan pada dosis fraksinasi $100+50$ Gy dan 100+100 Gy tidak terlihat perkembangan parasit bentuk skizon atau presentase parasitemia mendekati $0 \%$, tetapi pada variasi dosis fraksinasi $100+75$ Gy parasit bentuk skizon muncul pada pengamatan hari ke 11 dan terus mengalami peningkatan hingga hari ke 20 (Gambar 3). 


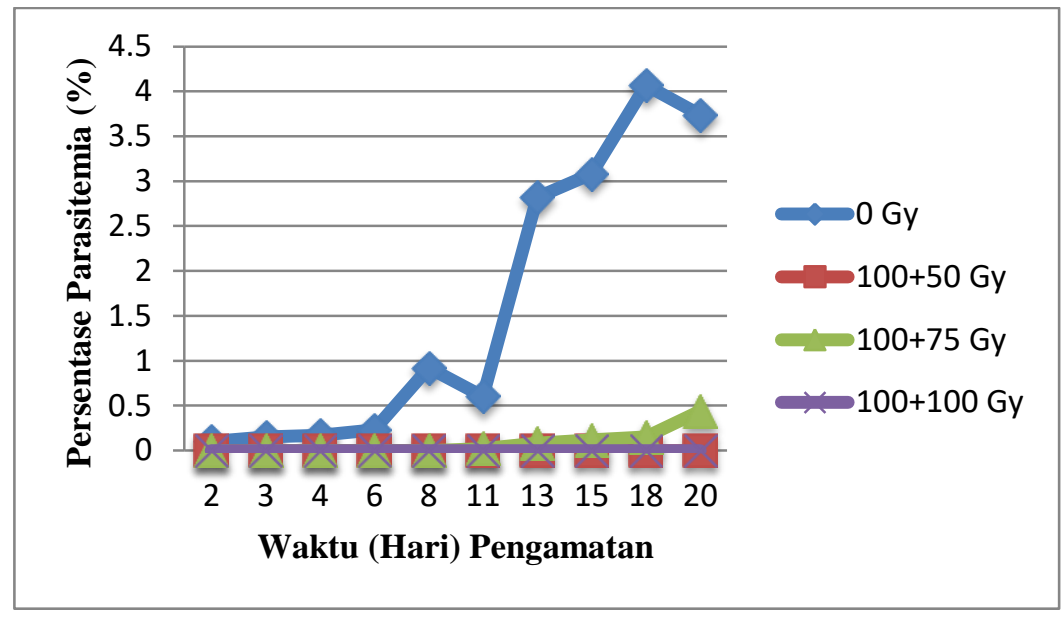

Gambar 3. Grafik persentase parasitemia stadium skizon dalam darah mencit setelah diiradiasi fraksinasi dengan variasi dosis fraksinasi $0 \mathrm{~Gy}, 100+50 \mathrm{~Gy}$, 100+75 Gy, 100+100 Gy (laju dosis 717 Gy/jam).

Kepadatan parasitemia secara keseluruhan (stadium tropozoit dan skizon) dapat dilihat bahwa persentase parasitemia kelompok dosis 0 Gy dari pengamatan hari ke 2 sampai hari ke 20 mengalami peningkatan yang sangat signifikan sampai mencapai sekitar 70\% (Gambar 4). Pada kelompok dosis fraksinasi 100+50 Gy persentase parasitemia jauh lebih rendah dibandingkan dengan kelompok kontrol. Pada kelompok dosis fraksinasi $100+75$ Gy persentase parasitemia mengalami peningkatan yang cukup signifikan pada hari 11, sedangkan pada kelompok dosis fraksinasi $100+100$ Gy persentase parasitemia tetap sangat rendah yakni sekitar $0,01 \%$.

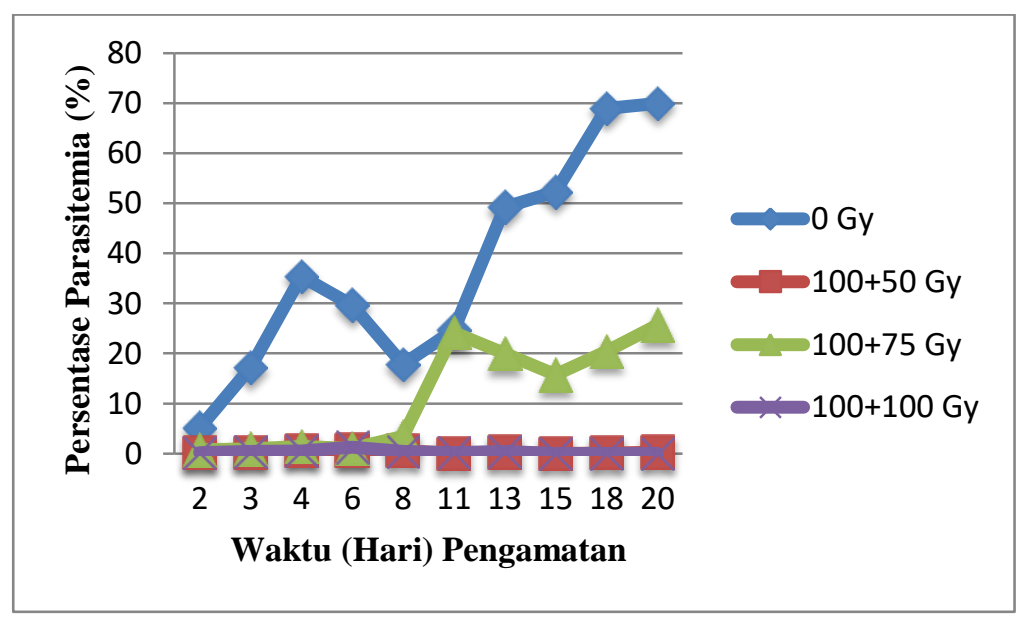

Gambar 4. Persentase parasitemia (stadium tropozoit dan skizon) dalam darah mencit setelah disuntik parasit iradiasi fraksinasi $0 \mathrm{~Gy}, 100+50 \mathrm{~Gy}, 100+75 \mathrm{~Gy}$, 100+100 Gy (laju dosis 717 Gy/jam). 
Pada penelitian ini terlihat bahwa variasi dosis fraksinasi $100+50$ Gy dan $100+100$ Gy adalah dosis yang optimum untuk melemahkan parasit $P$. berghei pada mencit, dimana dosis fraksinasi $100+100$ Gy adalah dosis yang paling optimum dalam melemahkan parasit $P$. berghei.

\section{Pengukuran berat badan mencit (hewan uji)}

Pada percobaan ini selain pengamatan persentase parasit dalam darah mencit (hewan uji) pasca penyuntikan, juga dilakukan pencatatan terhadap perubahan berat badan mencit. Dari penelitian dapat dilihat berat badan mencit terus mengalami penurunan pada variasi dosis $0 \mathrm{~Gy}$, $100+50$ Gy dan 100+75 Gy, tetapi tidak pada kelompok dosis $100+100$ Gy yang terus stabil.

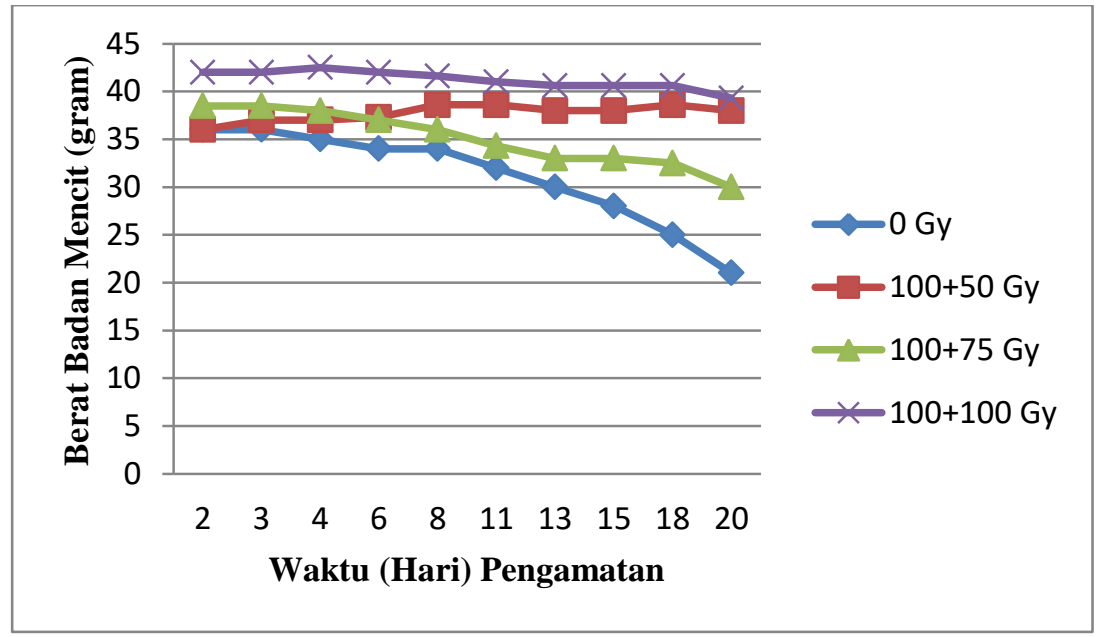

Gambar 5. Berat badan mencit pada hari-hari setelah disuntik parasit iradiasi fraksinasi $0 \mathrm{~Gy}, 100+50 \mathrm{~Gy}, 100+75 \mathrm{~Gy}, 100+100$ Gy (laju dosis 717 Gy/jam).

Dari hasil pengukuran tersebut dapat dilihat berat badan mencit mengalami penurunan dari hari pengamatan ke 2 sampai hari ke 20 untuk dosis 0 Gy (control), dosis fraksinasi $100+50$ Gy dan $100+75$ Gy tetapi tidak ditemukan pada kelompok dosis 100+100 Gy yang stabil di sepanjang hari pengamatan.

\section{Pengamatan hati dan limfa}

Infeksi parasit $P$. berghei menyebabkan jumlah sel darah merah mencit menurun pada hari pengamatan ke 20 dimana jumlah sel darah merah hanya tersisa $0,2 \%$ (terjadi anemia). Hati dan limfa mencit yang terinfeksi parasit $P$. berghei juga ditandai dengan pembengkakan dan perubahan warna pada hati dan limfa dari warna merah menjadi hitam (Gambar 6). 

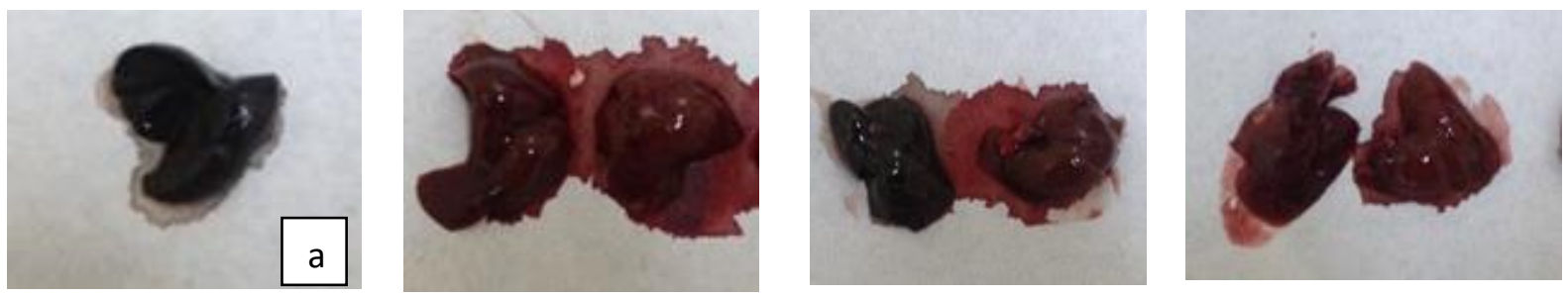

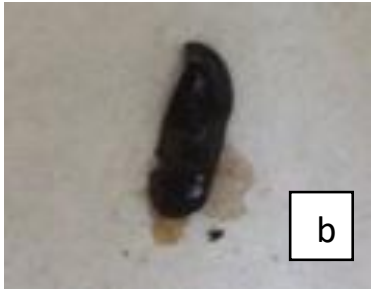

0 Gy

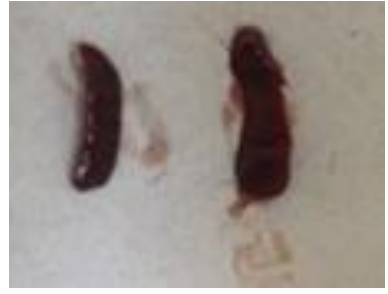

$100+50$ Gy

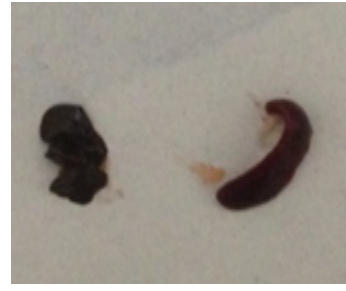

$100+75$ Gy

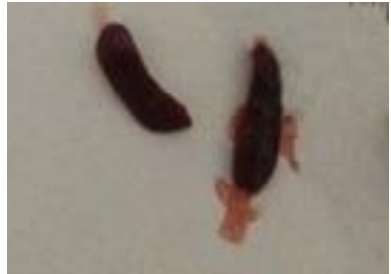

100+100 Gy

Gambar 6. Tampilan makroskopis hati (deret atas) dan limfa (deret bawah) mencit yang disuntik parasit iradiasi fraksinasi setelah pembedahan pada hari ke 20.

\section{Pembahasan}

Dalam penelitian ini telah dilakukan pengamatan parasitemia pada mencit untuk pengembangan vaksin malaria iradiasi, khususnya pemanfaatan dosis fraksinasi. Iradiasi gamma telah banyak digunakan untuk melemahkan parasit stadium darah (eritrositik) untuk pembuatan bahan vaksin. Iradiasi ini terbukti dapat menghambat pertumbuhan dan perkembangan parasit di dalam eritrosit dan menyebabkan reduksi parsial parasitemia. $^{7,9}$

Selain perubahan konsentrasi parasit dalam darah, penelitian ini juga mengevaluasi dosis fraksinasi berdasarkan tampilan organ hati dan limpa. Perubahan tampilan hati dan limfa merupakan petunjuk adanya infeksi parasit. Infeksi menyebabkan perubahan warna hati dan limpa menjadi coklat kehitaman karena parasit mengeluarkan pigmen hemozoin yang merupakan produk detoksifikasi parasit yang dilepaskan ke dalam peredaran darah ketika eritrosit yang terinfeksi sudah matang. Hemozoin digunakan oleh parasit untuk menghambat fungsi monosit dan tidak dapat berdiferensiasi menjadi sel dendritik. ${ }^{15}$ Sel dendritik ini berperan penting dalam inisiasi respon imun adaptif.

Pemanfaatan teknologi radiasi dalam pembuatan vaksin malaria telah digunakan sejak tahun 1967 oleh Nussenzweig yang melakukan iradiasi pada nyamuk yang membawa parasit pada kelenjar ludahnya. ${ }^{16}$ Nyamuk yang telah diiradiasi kemudian digigitkan ke mencit percobaan, dan setelah dilakukan uji tantang dengan menyuntikkan sporozoit infektif ke dalam tubuh mencit, sekitar $60 \%$ mencit tidak mengalami infeksi malaria. Percobaan ini merupakan titik awal dari sejumlah besar penelitian dan pengembangan vaksin malaria dengan menggunakan teknik nuklir. Berdasarkan penelitian yang sangat intensif, diketahui bahwa dosis optimal untuk melemahkan $P$. falciparum stadium sporozoit adalah antara 150 - $200 \mathrm{~Gy}{ }^{16,17}$

Penelitian tentang vaksin malaria yang ditujukan untuk memicu respon imun telah mengalami kemajuan yang luar biasa, 
namun masih menemui beberapa kendala karena melibatkan parasit yang struktur dan siklus hidupnya komplek yang dapat menyebabkan penyakit kronis pada manusia. Melalui pengkajian pada berbagai aspek biologi molekuler dan sel, epidemiologi dan imunologi, penelitian vaksin telah mencapai keberhasilan yang luar biasa menuju vaksin yang efektif. ${ }^{18}$ Penelitian antara lain membuktikan motilitas sporozoit dapat dihambat oleh serum dari mencit yang diimunisasi dan antibodi anti-sporozoit mampu memblok invasi sporozoit baik secara in vitro maupun in vivo. ${ }^{19}$ Penelitian lain pada manusia yang didemonstrasikan oleh paparan gigitan nyamuk yang sudah diinfeksi $P$. falciparum dan $P$. vivax dan diradiasi mampu memberikan imunitas steril serta proteksi komplit terhadap infeksi. $^{20}$ Beberapa tahun kemudian peneliti lain mengulangi eksperimen ini dan membuktikan bahwa imunisasi melalui gigitan nyamuk yang telah diinfeksikan dengan $P$. falciparum iradiasi memberikan imunitas steril dan reprodusibilitas imunitas yang tinggi pada manusia dan merupakan gold standar untuk pengembangan vaksin malaria. ${ }^{11}$

Dalam penelitian ini dievaluasi daya infektif parasit setelah diiradiasi fraksinasi. Radiasi fraksinasi merupakan radiasi berulang dengan dosis kecil, dan interval tertentu. ${ }^{21}$ Fraksinasi dalam terapi radiasi ditujukan untuk meningkatkan efek radiasi pada jaringan tumor dan untuk menurunkan efek radiasi pada jaringan normal. Efek samping akut terkait dengan singkatnya waktu fraksinasi, semakin singkat waktu total radiasi semakin tinggi efek samping akut radiasi. Sedangkan efek samping kronis berkaitan dengan besarnya dosis dalam setiap fraksi, semakin tinggi dosis per fraksi semakin tinggi efek samping kronis yang muncul. Dalam penerapannya, sistem fraksinasi dibuat dengan skema yang bervariasi, yang didasarkan pada skema dosis per fraksi, jumlah fraksi, interval waktu fraksi, ataupun berdasarkan perubahan dosis totalnya. $^{21,22}$ Berdasarkan hal tersebut maka perlu dilakukan atau diterapkan pada fraksinasi iradiasi $P$. berghei seperti yang telah dilakukan dalam penelitian ini.

\section{Kesimpulan}

Disimpulkan bahwa iradiasi fraksinasi 100+100 Gy paling efektif melemahkan parasit $P$. berghei sebagai bahan untuk pembuatan vaksin malaria. Hal ini didukung oleh berat badan mencit yang stabil dan tampilan makroskpois organ hati dan limpa mencit pada hari-hari pengamatan.

\section{Daftar Rujukan}

1. World Malaria Report 2018, World Health Organization, Geneva, 2018.

2. Fola AA, Harrison GLA, Hazairin MH, Barnadas C, Hetzel MW, Iga $\mathrm{J}$ et al. Higher complexity of infection and genetic diversity of Plasmodium vivax than Plasmodium falciparum across all malaria transmission zones of Papua New Guinea. Am J Trop Med Hyg. 2017; 96(3): 630-641.

3. Basuki S, Fitriah, Risamasu PM, Kasmijati, Ariami P, Sugeng Riyanto S, et al. Origins and spread of novel genetic variants of sulfadoxine-pyrimethamine resistance in Plasmodium falciparum isolates in Indonesia. Malar J. 2018; 17: 475.

4. Syafruddin D, Asih PBS, Casey GJ, et al. Molecular epidemiology of Plasmodium falciparum resistance to antimalarial drugs In Indonesia. J Am Trop Med Hyg. 2005; 72: 174-181.

5. Kusriastuti R, Surya A. New treatment policy of malaria as a part of malaria control program in Indonesia. Acta Medica Indonesiana - The Indonesian Journal of Internal Medicine. 2012; 44: 265-269.

6. Feachem SR. Roll Back Malaria: an historical footnote. Malaria Journal 2018; 17: 433.

7. Syaifudin M, Tetriana D, Darlina, Nurhayati $\mathrm{S}$. The feasibility of ionizing radiation as a tool for developing malaria vaccine. Atom Indonesia. 2011 Desember; 37(3): 91-101.

8. Darlina, Prapmaningtyas CA, Kisnanto T. Evaluasi efektivitas kemopropilaksis klorokuin terhadap bahan vaksin malaria radiasi secara in vivo. Prosiding Pertemuan dan Presentasi Ilmiah Penelitian Dasar Ilmu Pengetahuan dan Teknologi Nuklir, 9 Agustus 2016, hal. 21-25.

9. Syaifudin, M. Peranan faktor imun dan profil 
protein dalam penelitian dan pengembangan vaksin malaria iradiasi. Biosaintifika. 2014; 6(1): 8-17.

10. Syaifudin M, Darlina, Rahardjo T, Tetriana D, Nurhayati S, Surniyantoro HES et al. Efectiveness of gamma rays in attenuating rodent malaria parasites of Plasmodium berghei in blood of mice. Atom Indonesia. 2013 Apr; 39(1): 19-23.

11. Darlina, Kisnanto T., Fauzan A. Respons hematopoitik mencit yang diinfeksi dengan Plasmodium berghei stadium eritrosit iradiasi gamma. Prosiding Seminar Pusat Teknologi Keselamatan dan Metrologi Radiasi BATAN, hal. 85-94, 2012.

12. Liu W, Haley $\quad \mathrm{BM},{ }^{1}$ Kwasny $\mathrm{MJ}, \quad \mathrm{Li}$ JJ, Grdina DJ, Paunesku T, and Woloschak GE. The effects of radiation and dosefractionation on cancer and non-tumor disease development. Int $\mathbf{J}$ Environ Res Public Health. 2012 Dec; 9(12): 4688-4703.

13. Hall E.J., Giaccia A.J. Radiobiology for the Radiologist. Lippincott Williams \& Wilkins; Philadelphia, PA, USA: 2006. p. 339.

14. Center for Diseases Controls. 2014. Laboratory Diagnosis of Malaria Determination of Parasitemia. Diunduh dari: http://www.cdc.gov/dpdx/resources/pdf/benc hAids/malaria/Parasitemia_andLifeCycle.pdf. Diakses pada: 12 Maret 2014.

15. Amorim KNS, Chagas DCG, Sulczewski FB, Boscardin SB. Dendritic cells and their multiple roles during malaria infection. J Immunol Res. 2016; 2016: 2926436.

16. Hoffmann SL. Ruth Nussenzweig (19282018) malaria vaccine and immunology pioneer. Am J Trop Med Hyg. 2018 Aug; 99(2): 253-254.

17. Fernandez-Arias C, Arias CF, Zhang $\mathrm{M}$, Herrero MA, Acosta FJ, Tsuji M. Modeling the effect of boost timing in murine irradiated sporozoite prime-boost vaccines. PLoS ONE 2018; 13(1): e0190940.

18. Proietti $\mathrm{C}$ and Doolan DL. The case for a rational genome-based vaccine against malaria. Front. Microbiol. 2015; https://doi.org/10.3389/fmicb.2014.00741.

19. Jing H, Xiangming L, Reis CD, Jordana G A, Min Z, Robert M, et al. Human immune system mice immunized with Plasmodium falciparum circumsporozoite protein induce protective human humoral immunity against malaria. Journal of Immunological Methods. 2015 Sep; 42-50.

20. Sedegah M, Hedstrom R, Hobart P, Hoffman SL. Protection against malaria by immunization with plasmid DNA encoding circumsporozoite protein. Proc Natl Acad Sci USA. 1994; 91: 9866-9870.

21. Hellevik $\mathrm{T}$ and Martinez-Zubiaurre $\mathrm{I}$.
Radiotherapy and the tumor stroma: the importance of dose and fractionation. Front Oncol. 2014; 4: 1.

22. Kim YJ, Cho KH, Kim JY, Lim YK, Min HS, Lee $\mathrm{SH}$, et al. Single-dose versus fractionated stereotactic radiotherapy for brain metastases. Int J Radiat Oncol Biol Phys. 2011; 81:483-910. 